\section{Smartphone Use and Online Search and Purchase Behavior of North Americans: Gardening and Non- gardening Information and Products}

\author{
Bridget K. Behe ${ }^{1,6}$ \\ Department of Horticulture, Michigan State University, 1066 Bogue Street, \\ Room A238, East Lansing, MI 48824
}

\author{
Benjamin L. Campbell ${ }^{2}$ \\ Department of Agricultural and Resource Economics, University of \\ Connecticut, 3107 Horsebarn Hill Road, U-4021, Storrs, CT 06269
}

Charles R. Hall ${ }^{1,3}$

Department of Horticultural Sciences, Texas A\&M University, 2133 TAMU, College Station, TX 77843

\begin{abstract}
Hayk Khachatryan ${ }^{2}$
Department of Food and Resource Economics, University of Florida, MidFlorida Research and Education Center Institute of Food and Agricultural Sciences, 2725 S. Binion Road, Apopka, FL 32703

\section{Jennifer H. Dennis ${ }^{4}$}

Department of Horticulture and Landscape Architecture and jointly with Department of Agricultural Economics, Hort Building, Purdue University, 625 Agriculture Mall Drive, West Lafayette, IN 47907
\end{abstract}

\section{Chengyan Yue ${ }^{4,5}$ \\ Department of Horticultural Sciences and jointly with Department of Applied Economics, University of Minnesota, 458 Alderman Hall, 1970 Folwell Avenue, St. Paul, MN 55108}

Additional index words. consumer, information, search, smartphone, survey

\begin{abstract}
Information plays a vital role in the purchase decisions of retail lawn and garden consumers. Consumers have readily adopted personal computers and Internet technology as a way of seeking information and/or making purchases online. However, the extent to which horticultural consumers specifically seek information and make purchases online is not well documented. Our interests for this project were driven by an interest in the impact of smartphone ownership and Internet search behavior on product purchasing related to gardening products and items and how search and purchase were similar to (or different from) non-gardening information and products. Given the sharp rise in the use of smartphones and mobile media use, we explored differences among online shoppers, specifically those who had searched online for gardening information with those who were online for other purposes. We found differences between those who had searched online for non-gardening information compared with those who had searched online for gardening information. Women were more likely to search online for both gardening and non-gardening information, but men were more likely to make online gardening purchases. Education level, ethnicity, and geographic location of residence had varying impacts on the likelihood of online search and purchase. Having searched online for nongardening information increased the likelihood of an online purchase by $16 \%$, whereas the likelihood of purchase increased to $19 \%$ for online gardening-related searches.
\end{abstract}

\footnotetext{
Received for publication 27 Nov. 2012. Accepted for publication 8 Jan. 2013.

${ }^{1}$ Professor.

${ }^{2}$ Assistant Professor.

${ }^{3}$ Ellison Endowed Chair in International Floriculture. ${ }^{4}$ Associate Professor.

${ }^{5}$ Bachman Endowed Chair in Consumer Horticulture.

${ }^{6}$ To whom reprint requests should be addressed; e-mail behe@msu.edu.
}

Information has come to play an increasingly vital role in the purchasing decision for many products. As technologies have evolved (e.g., personal computers, smartphones, etc.), information availability and accessibility have moved from being cost-prohibitive as a result of time and energy constraints to being an inexpensive, instantly available component of many consumers' shopping repertoire
(TechBargains.com, 2012). In addition to the proliferation of instant information, technology has enabled shopping to move from the showroom floor of a retail outlet to online. Through the use of mobile technologies (e.g., smartphones), consumers can now expand their online shopping experience by accelerating online and in-store purchases on the customer's terms. A smartphone is defined as a cellular telephone with built-in applications and Internet access (PC World, 2012). The successful adoption of mobile technology has not only encouraged organizations to continue investing in it in 2012, but has also led them to hire more employees with mobile skills and to build on existing programs to find new ways to engage connected consumers (Caron, 2012; Oracle Endeca, 2012).

The prevalence of mobile technology has rapidly spread (McKinsey \& Company, 2011). According to the Mobile Future Focus Report, Year 2011 proved to be a groundbreaking year for the mobile industry with consumers increasingly integrating mobile behaviors into their lifestyles. Mobile behaviors would include online search, purchase, and use of applications or apps. As mobile channels present a more personal, social, and ubiquitous experience to consumers, advertisers and publishers have an opportunity to better engage target audiences. The report ranked "retail purchasing" as the second-highest mobile media category in the United States followed by "other commerce-related" categories such as electronic payments and auction sites. More than half of the U.S. smartphone population used their phone to perform retail research while inside a store in 2011, illustrating the emergence of savvy smartphone shoppers who bring online shopping behaviors in-store. At the end of 2011, nearly one in five smartphone users scanned product barcodes, and nearly one in eight compared prices on their phone while in a store.

The comScore 2012 Mobile Future in Focus report found that nearly $42 \%$ of all U.S. mobile subscribers now use a smartphone (comScore, 2012). Among consumers most likely to use a smartphone, consumers aged 18 to 29 years were the most active demographic during 2011 with 33\% using their phone for more than six activities per day (InsightExpress, 2012). However, one-third (33\%) of all consumers (not just the younger demographic) used their phone specifically for online information while inside a physical store either for product reviews or pricing information during the 2011 holiday season (Pew Research Center, 2012). The percentages found by the Pew Research Center (2012) are not unique but similar to other studies including Freedman (2011), (Google/IPSOS, 2011), Oracle ATG Web Commerce (2011), and PriceGrabber. com (2011).

With the increased consumer reliance on Internet-based technologies, it is essential for green industry firms to understand the impact of new technologies on their business. Total green industry sales in 2008 were estimated at $\$ 27.14$ billion, and total industry employment was estimated at 262,941 permanent and 
temporary jobs (Hodges et al., 2010). As noted by Mason et al. (2008), 85\% of consumers in their survey indicated they would be willing to visit an Internet web site that provides more information on how to care for and maintain a container garden. Furthermore, Behe et al. (2008) conducted the first investigations of online search and purchase studies related to plants and gardening. Their objectives were to provide baseline information for horticultural firms considering establishing an online presence either for information-seekers or plant- and related product purchases. They found that nearly $28 \%$ of U.S. consumers searched for gardening information at least once in the year before the study, 2007; of those, more than $50 \%$ searched for information at least weekly. Behe et al. (2008) did find differences in gardening-related searches by age and marital status but not by region of residence, income, or gender. They also found that all online gardening purchasers were also in-person purchasers with one lone exception. Results of these studies show that there is a potential to increase sales by taking advantage of the mobile technology boom.

Our research sought to compare smartphone and Internet use of gardening consumers with those of consumers at large. Specifically, we compare consumers who searched online for gardening and non-gardening-related information and also compare those consumers who made online gardening and non-gardeningrelated purchases. Our hypothesis is that consumers who search online for non-gardening information are demographically and behaviorally similar to those who search online for gardening information (Hypothesis 1). Furthermore, we hypothesize that those who make online purchases of non-gardening products are similar to those who make gardening online purchases (Hypothesis 2). Lastly, we hypothesize that searching for gardening information online increases the likelihood of an online gardening purchase (Hypothesis 3 ). The results of this study are also compared with previously cited gardening-related research by Behe et al. (2008) to determine how much gardening-related online search and purchasing behavior has changed over the last five

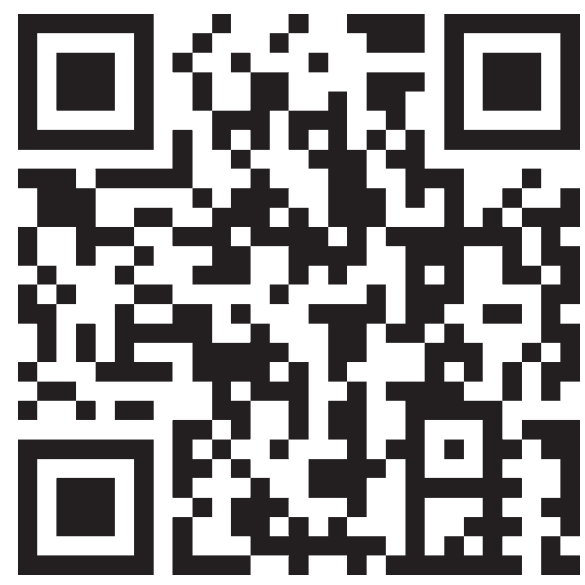

Fig. 1. Sample quick response (QR) code shown to survey participants. years. Finally, we extend the work of Behe et al. (2008) by comparing U.S. and Canadian consumers, which offers new insights into the behaviors of consumers in these two markets.

\section{Methods}

To accomplish our objectives, we implemented an online survey of both U.S. and Canadian consumers in May 2011. The survey instrument was adapted from prior instruments, namely the instrument used in Behe et al. (2008). The survey included questions regarding smartphone ownership (the sole criteria for smartphone use), frequency of Internet use, incidence of Internet-based (mobile and desktop) information search and purchasing of gardening and non-gardening products, and familiarity with quick response $(\mathrm{QR})$ codes (Fig. 1). We specifically asked participants if they had seen a QR code as a separate question from Internet search behavior. Gardening was defined in Behe et al. (2008) and this survey as any search or purchase that was of plants or related to plants. The survey instrument and protocol were approved by the university Institutional Review Board. Participants were recruited from a panel maintained by Global Market Insite, Inc. (Bellevue, WA) and directed to our online survey with no compensation beyond what Global Market Insite, Inc. uses to maintain the panel.

With increasing trade of horticultural products between the United States and Canada since the adoption of North American Free Trade Agreement (NAFTA), it is essential for producers and retailers to understand if these consumers have differing use patterns of mobile technology as it relates to searching and purchasing horticultural products. Consumers surveyed represented the 48 contiguous states, Washington, DC, and all Canadian provinces. Given the geographic diversity of the sample, we used an online survey. Advantages of web-based surveys according to McCullough (1998) are that they are potentially faster to conduct than telephone or face-to-face interviews, generate more accurate information with less human error, and are less expensive by several magnitudes because less labor is needed to create, deliver, and analyze the survey. Other advantages over mail, telephone, or fax surveys are the fast rate in which high-quality responses can be ascertained. Thousands of surveys can be transmitted at a time, they are automatically coded, and the data are collected in a cost-effective manner (Dillman et al., 2009). However, households in the Global Market Insite, Inc. panel without a computer or Internet access would be omitted from potential selection. An estimated 23\% of American homes had no computer or Internet access in 2011 (U.S. Department of Commerce, Economics \& Statistics Administration, 2011), although this percentage likely declines each year.

After collecting the data, we took a cursory look at smartphone and QR use with Stata software (College Station, TX). We then examined the role of demographic and behavior variables on having searched or purchased both gardening and non-gardening products. Because the dependent variable was binary in nature (searched online or not and purchased

Table 1. Summary statistics of 2511 North American participants in an online survey conducted during May 2011 to elicit gardening-related search and purchase behaviors.

\begin{tabular}{|c|c|c|}
\hline Variable & Mean & SD \\
\hline Household income (thousand dollars) & $\$ 65,702$ & $\$ 42,477$ \\
\hline Age (years) & 37.96 & 14.73 \\
\hline Gender (percent female) & 0.45 & 0.50 \\
\hline Number of persons $\geq$ adults in household & 2.57 & 1.23 \\
\hline Number of persons $\geq$ children in household & 1.66 & 1.01 \\
\hline Percent Caucasian (compared with "other ethnic" base) & 0.79 & 0.41 \\
\hline Percent African/Caribbean (compared with "other ethnic" base) & 0.05 & 0.23 \\
\hline Percent Hispanic (compared with "other ethnic" base) & 0.05 & 0.21 \\
\hline Percent living in metropolitan area (compared with rural) & 0.27 & 0.44 \\
\hline Percent living in suburban area (compared with rural) & 0.53 & 0.50 \\
\hline Region: northeast U.S. (compared with west U.S.) & 0.17 & 0.38 \\
\hline Region: midwest U.S. (compared with west U.S.) & 0.17 & 0.38 \\
\hline Region: south U.S. (compared with west U.S.) & 0.18 & 0.39 \\
\hline Region: west Canada (compared with west U.S.) & 0.03 & 0.18 \\
\hline Region: Ontario, Canada (compared with west U.S.) & 0.12 & 0.32 \\
\hline Region: Atlantic Canada (compared with west U.S.) & 0.12 & 0.33 \\
\hline Region: British Columbia, Canada (compared with west U.S.) & 0.04 & 0.19 \\
\hline Region: northern Canada (compared with west U.S.) & 0.00 & 0.03 \\
\hline Region: Quebec (compared with west U.S.) & 0.01 & 0.07 \\
\hline Education: some college (compared with high school or less) & 0.41 & 0.49 \\
\hline Education: Bachelor's degree (compared with high school or less) & 0.27 & 0.44 \\
\hline Education: greater than Bachelor's degree (compared with high school or less) & 0.11 & 0.31 \\
\hline Owned a smartphone & 0.46 & 0.50 \\
\hline Smartphone Internet/app use: days per week & 1.80 & 3.05 \\
\hline Had seen the QR code or symbol & 0.66 & 0.47 \\
\hline Garden expenditures during last six months & $\$ 103.97$ & $\$ 112.89$ \\
\hline Sought information but not about gardening & 0.85 & 0.36 \\
\hline Sought information about gardening & 0.47 & 0.50 \\
\hline Made an online purchase non-gardening-related & 0.55 & 0.50 \\
\hline Made an online purchase gardening-related & 0.18 & 0.39 \\
\hline
\end{tabular}

$\mathrm{QR}=$ quick response. 
online or not), we used a binary probit model. The binary probit probability can be expressed as

$$
\mathrm{P}(\mathrm{Y}=1 \mid \mathrm{x})=\Phi\left(\mathrm{x}^{\prime} \beta\right)
$$

where $\Phi(\mathrm{x})$ is the cumulative standard normal distribution (Davidson and MacKinnon, 1993, p. 514) and $x$ is a set of explanatory variables such as demographics and purchase behaviors. However, for direct application, the probit coefficients are difficult to interpret. The marginal effects, however, are easier to interpret and provide a means by which to provide actionable consumer profiles. The marginal effects have varying interpretations depending on the type of variable. For instance, the marginal effect for a continuous variable can be a percentage increase or decrease in the probability of searching for (or purchasing) a product given a one-unit increase in the mean. For the non-continuous (i.e., dummy) variable, the interpretation is an increase or decrease in the probability of searching for (or purchasing) from the pre-defined "base" category.

\section{Results}

A total of 2511 consumers completed the survey. The mean household income of the sample was $\$ 65,702$ (Table 1), $\$ 3,429$ higher than the median U.S. family household income at $\$ 62,273$ (DeNavis-Walt, et al., 2012) but $\$ 10,980$ lower than the mean Canadian family income at $\$ 76,600$ (Statistics Canada c, 2012). Our sample demographics mirror those of the United States and Canada for both age and income. The U.S. Census reported that the mean age is 37.2 years with $51 \%$ of the population being male, whereas Statistics Canada reports a median age of 39.9 years old and $53 \%$ male population (Statistics Canada a, 2012). The sample had a mean age of nearly 38 years with 2.6 adults and 1.7 children in the household. Slightly more than one-fourth lived in metropolitan areas, whereas slightly more than half lived in suburban areas. The sample was geographically well dispersed throughout North America; $68 \%$ of the participants were American and $32 \%$ were Canadian. Forty-one percent reported their education level as "some college," whereas $27 \%$ had a Bachelor's degree. Given ethnic groups are thought of in different lights by the U.S. and Canadian censuses, we used the more general guidelines used by the U.S. Census where respondents were asked to choose their ethnicity from Caucasian, African descent, Hispanic/Latino, or other. According to the U.S. Census, $74.7 \%$ of the population is Caucasian, $12 \%$ are of African descent, and $14.2 \%$ are Hispanic or Latino (American Fact Finder, 2012); Statistics Canada indicates the Canadian population is made up of $90 \%+$ Caucasian (dependent on which nationalities are included), $0.7 \%$ African descent, and $0.3 \%$ Hispanic or Latino (Statistics Canada b, 2012). Our sample was 79\% Caucasian, 5\% African descent, 5\% Hispanic descent, and 11\% multiple/other ethnic group(s).

Online search behavior. Of the total sample, $45.7 \%$ owned a smartphone and searched online an average of $1.8 \mathrm{~d}$ per week, and $65.9 \%$ had seen a QR code image. Eightyfive percent had used the Internet in the three months before the study to search for nongardening-related information. However, only $47 \%$ of the study participants had searched for gardening-related information. Average gardening-related expenditures in the six months before the study were $\$ 103.97$ with $18 \%$ purchasing $\$ 0$. Nearly $55 \%$ had purchased something online (either from their smartphone or a computer) that was not gardeningrelated, but only $18 \%$ had purchased something gardening-related from an online source.

Behe et al. (2008) reported that of 1610 U.S. survey respondents, nearly $90 \%$ of those study participants had sought online information (non-gardening-related) in the year before the survey, but only $27 \%$ of participants in that study had searched for gardeningrelated information online. Nearly $50 \%$ of the Behe et al. (2008) sample had made an online purchase not gardening-related, and $7.4 \%$ had made a gardening-related online purchase. Thus, information gardening searches has nearly doubled in the time between our study and Behe et al. (2008). Also, our study showed that purchases of gardening-related products

Table 2. Comparison of 2511 North American survey participants who searched online (by smartphone or other connected device) for non-gardening information in the three months before the study with those who did not.

\begin{tabular}{|c|c|c|c|c|}
\hline \multirow[b]{2}{*}{ Variables } & \multicolumn{4}{|c|}{$\begin{array}{l}\text { Sought information but } \\
\text { not about gardening }\end{array}$} \\
\hline & Coefficients ${ }^{\mathrm{z}}$ & $\begin{array}{c}P \\
\text { value }\end{array}$ & $\begin{array}{c}\text { Marginal } \\
\text { effects }\end{array}$ & $\begin{array}{c}P \\
\text { value }\end{array}$ \\
\hline Household income (thousand dollars) & 0.0007 & 0.422 & 0.0002 & 0.422 \\
\hline Age (years) & 0.0008 & 0.732 & 0.0002 & 0.732 \\
\hline Gender (percent female) & 0.2452 & 0.000 & 0.0542 & 0.000 \\
\hline Number of persons $\geq$ adults in household & -0.0833 & 0.001 & -0.0187 & 0.001 \\
\hline Number of persons $\geq$ children in household & -0.0056 & 0.857 & -0.0013 & 0.857 \\
\hline Race: Caucasian (compared with "other ethnic" base) & 0.2986 & 0.002 & 0.0731 & 0.005 \\
\hline $\begin{array}{l}\text { Race: African/Caribbean } \\
\text { (compared with "other ethnic" base) }\end{array}$ & -0.3008 & 0.040 & -0.0771 & 0.067 \\
\hline Race: Hispanic (compared with "other ethnic" base) & 0.0266 & 0.868 & 0.0059 & 0.866 \\
\hline Live in metropolitan area (compared with rural) & -0.0793 & 0.398 & -0.0181 & 0.407 \\
\hline Live in suburban area (compared with rural) & 0.0795 & 0.343 & 0.0179 & 0.344 \\
\hline Region: northeast U.S. (compared with west U.S.) & 0.0365 & 0.727 & 0.0081 & 0.724 \\
\hline Region: midwest U.S. (compared with west U.S.) & 0.1442 & 0.182 & 0.0307 & 0.159 \\
\hline Region: south U.S. (compared with west U.S.) & 0.1989 & 0.061 & 0.0416 & 0.044 \\
\hline Region: west Canada (compared with west U.S.) & 0.3137 & 0.128 & 0.0595 & 0.065 \\
\hline Region: Ontario, Canada (compared with west U.S.) & 0.3880 & 0.002 & 0.0736 & 0.000 \\
\hline Region: Atlantic Canada (compared with west U.S.) & 0.1469 & 0.209 & 0.0310 & 0.180 \\
\hline $\begin{array}{l}\text { Region: British Columbia, Canada } \\
\text { (compared with west U.S.) }\end{array}$ & 0.3603 & 0.053 & 0.0668 & 0.016 \\
\hline Region: Quebec (compared with west U.S.) ${ }^{\mathrm{y}}$ & -0.4841 & 0.222 & -0.1359 & 0.305 \\
\hline $\begin{array}{l}\text { Education: some college } \\
\text { (compared with high school or less) }\end{array}$ & 0.1005 & 0.225 & 0.0223 & 0.220 \\
\hline $\begin{array}{l}\text { Education: Bachelor's degree } \\
\text { (compared with high school or less) }\end{array}$ & 0.0911 & 0.332 & 0.0200 & 0.320 \\
\hline $\begin{array}{l}\text { Education: greater than Bachelor's degree } \\
\text { (compared with high school or less) }\end{array}$ & 0.0518 & 0.669 & 0.0114 & 0.662 \\
\hline Smartphone Internet/app use: days per week & 0.0109 & 0.335 & 0.0024 & 0.334 \\
\hline Had seen the QR code or symbol & 0.2128 & 0.001 & 0.0494 & 0.002 \\
\hline Garden expenditures during last six months & -0.0005 & 0.076 & -0.0001 & 0.076 \\
\hline Constant & 0.5362 & 0.009 & - & - \\
\hline Wald $\chi^{2}$ & & & 100.6 & \\
\hline$P$ value & & & 0.000 & \\
\hline log pseudolikelihood & & & 1025.8 & \\
\hline
\end{tabular}

${ }^{\mathrm{z}}$ Coefficients are multiplied by 1000 .

${ }^{y}$ Consumers of northern Canadian provinces are excluded from the analysis because there is too little variation within the dependent variable.

$\mathrm{QR}=$ quick response.

Bold text denotes significant difference at $p<0.10$. online increased almost three-fold in that same time. Our findings help to document the tremendous increase in technology use in general and among horticultural consumers.

We found 10 differences between study participants who had searched for non-gardening information compared with those who had not searched for non-gardening-related information (Table 2 ). Women were $5 \%$ more likely to have searched for non-gardening-related information online in the three months before the survey compared with men. Households with a fewer number of adults (persons older than age 18 years) were $2 \%$ more likely to search online for non-gardening-related information. Caucasian participants were 7\% more likely to have made non-gardening online searches, whereas African/Caribbean participants were $8 \%$ less likely to have made those searches compared with other ethnic groups. Study participants from the southern United States, west Canada, Ontario, Canada, and British Columbia, Canada, were $4 \%, 6 \%$, $7 \%$, and $7 \%$ more likely to have searched for online gardening information, respectively, compared with participants from the western United States. Those who had searched for non-gardening-related information online 
were 5\% more likely to have seen a QR code or symbol. This is reasonable, especially because $46 \%$ of the entire sample owned a smartphone and may have used that device for some online searches. Increased gardening expenditures reduced the probability of hood of searching for non-gardening-related information included age, number of children in the household, area of residence in metropoland education level. Several findings were surprising given the results of the Pew Research Center (2012) study, namely the nonsignificance of residence (urban/metro) and age.

Several differences emerged when we compared those who sought gardening information online compared with those who did likelihood of gardening online searches, which we did not observe for non-gardening searches. Females were $4 \%$ more likely to search for gardening-related information online, consistent with a higher likelihood of females searchonline search for non-gardening product information. Variables not affecting the likeliitan/suburban/rural areas, household income, not (Table 3). Increased income reduced the

ing for non-gardening information. Women comprise the primary demographic of garden purchases (Behe et al., 2010). Participants who lived in households with more adults (persons older than age 18 years) were $2 \%$ more likely to have searched for gardeningrelated information online, opposite of the findings related to searching for information for non-gardening products. Being of Caucasian descent slightly decreased the likelihood of seeking online gardening information, which was not consistent with the ethnic heritage of those who purchase most of the gardening-related products (Dennis and Behe, 2007). Dennis and Behe (2007) showed that most purchasers of plants and gardeningrelated products were, in fact, Caucasian. However, they showed that those differences declined in magnitude as income level increased. Our findings in this study may be an indication that online information is potentially reaching a new market segment. Compared with participants living in rural areas, participants who lived in metropolitan or suburban areas were less likely to seek gardening-related information online.

Table 3. Comparison of 2511 North American survey participants who searched online (by smartphone or other connected device) for gardening information in the three months before the study with those who did not.

\begin{tabular}{|c|c|c|c|c|}
\hline \multirow[b]{2}{*}{ Variables } & \multicolumn{4}{|c|}{ Sought information about gardening } \\
\hline & Coefficients $^{z}$ & $\begin{array}{c}P \\
\text { value }\end{array}$ & $\begin{array}{c}\text { Marginal } \\
\text { effects }\end{array}$ & $\begin{array}{c}P \\
\text { value }\end{array}$ \\
\hline Household income (thousand dollars) & -0.0020 & 0.008 & -0.0008 & 0.008 \\
\hline Age (years) & 0.0027 & 0.201 & 0.0011 & 0.201 \\
\hline Gender (percent female) & 0.1107 & 0.041 & 0.0440 & 0.041 \\
\hline Number of persons $\geq$ adults in household & 0.0493 & 0.037 & 0.0196 & 0.037 \\
\hline Number of persons $\geq$ children in household & -0.0012 & 0.966 & -0.0005 & 0.966 \\
\hline $\begin{array}{l}\text { Race: Caucasian } \\
\text { (compared with "other ethnic" base) }\end{array}$ & -0.1557 & 0.080 & -0.0620 & 0.080 \\
\hline $\begin{array}{l}\text { Race: African/Caribbean } \\
\text { (compared with "other ethnic" base) }\end{array}$ & -0.0713 & 0.607 & -0.0283 & 0.606 \\
\hline $\begin{array}{l}\text { Race: Hispanic } \\
\text { (compared with "other ethnic" base) }\end{array}$ & -0.2188 & 0.161 & -0.0857 & 0.152 \\
\hline Live in metropolitan area (compared with rural) & -0.2685 & 0.001 & -0.1057 & 0.001 \\
\hline Live in suburban area (compared with rural) & -0.2858 & 0.000 & -0.1133 & 0.000 \\
\hline Region: northeast U.S. (compared with west U.S.) & -0.0433 & 0.642 & -0.0172 & 0.642 \\
\hline Region: midwest USA (compared with west U.S.) & -0.0316 & 0.735 & -0.0125 & 0.734 \\
\hline Region: south U.S. (compared with west U.S.) & -0.1055 & 0.250 & -0.0418 & 0.248 \\
\hline Region: west Canada (compared with west U.S.) & -0.0698 & 0.659 & -0.0277 & 0.658 \\
\hline Region: Ontario, Canada (compared with west U.S.) & 0.0777 & 0.446 & 0.0309 & 0.447 \\
\hline Region: Atlantic Canada (compared with west U.S.) & -0.1307 & 0.202 & -0.0517 & 0.199 \\
\hline $\begin{array}{l}\text { Region: British Columbia, Canada } \\
\text { (compared with west U.S.) }\end{array}$ & 0.0600 & 0.694 & 0.0239 & 0.694 \\
\hline Region: Quebec (compared with west U.S.) ${ }^{\mathrm{y}}$ & 0.4483 & 0.191 & 0.1756 & 0.170 \\
\hline $\begin{array}{l}\text { Education: some college } \\
\text { (compared with high school or less) }\end{array}$ & 0.0830 & 0.244 & 0.0330 & 0.244 \\
\hline $\begin{array}{l}\text { Education: Bachelor's degree } \\
\text { (compared with high school or less) }\end{array}$ & 0.0175 & 0.828 & 0.0070 & 0.828 \\
\hline $\begin{array}{l}\text { Education: greater than Bachelor's degree } \\
\text { (compared with high school or less) }\end{array}$ & 0.0887 & 0.397 & 0.0353 & 0.398 \\
\hline Smartphone Internet/app use: days per week & 0.0364 & 0.000 & 0.0145 & 0.000 \\
\hline Had seen the QR code or symbol & -0.0126 & 0.829 & -0.0050 & 0.829 \\
\hline Garden expenditures during last six months & 0.0044 & 0.000 & 0.0018 & 0.000 \\
\hline Constant & -0.3968 & 0.028 & - & - \\
\hline Wald $\chi^{2}$ & & & 269.6 & \\
\hline$P$ value & & & 0.000 & \\
\hline log pseudolikelihood & & & 1556.0 & \\
\hline
\end{tabular}

${ }^{\mathrm{z} C o e f f i c i e n t s ~ a r e ~ m u l t i p l i e d ~ b y ~} 1000$.

${ }^{y}$ Consumers of Northern Canadian provinces are excluded from the analysis because there is too little variation within the dependent variable.

$\mathrm{QR}=$ quick response.

Bold text denotes significant difference at $p<0.10$.
This finding is consistent with the Pew Research Center (2012) study in that rural consumers were less likely to seek product reviews for a product they could find in a store. This may be the result of their ability to access information in person from local garden centers or other plant retailers. Those who searched for gardening-related information online were more likely to have used a smartphone more frequently and more likely to have spent more money on gardening expenditures. Seeing a QR code did not change the likelihood of searching online for gardening information.

Hypothesis 1 was not supported given there were more and different significant differences between those who had searched online for non-gardening information compared with those who had searched for gardening-related information.

Online purchase behavior. We compared participants who had made an online purchase (non-gardening-related) with participants who had not made an online purchase (non-gardening-related) and found 10 differences (Table 4). Three differences related to geographic location of residence and three related to education level. Participants who were from Ontario, Canada, west Canada, and Atlantic Canada were $7 \%, 11 \%$, and $16 \%$ less likely, respectively, to have made an online purchase of a non-gardening item compared with participants from the western United States. Participants, who had completed at least some college, compared with high school or less, were at least $11 \%$ more likely to have made an online purchase. However, smartphone use slightly decreased the likelihood of making an online purchase. We speculate this may be the result of a preference to purchase in person (perhaps for security issues) but being more comfortable searching for information online. Having seen a QR code increased the probability of making an online purchase by $7 \%$, which may be an indication of comfort with technology for searching for information. Gardening expenditures slightly increased the likelihood of making a non-gardening online purchase, but seeking information substantially increased the likelihood of an online non-gardening purchase. Having sought information about non-gardening products online increased the likelihood of an online purchase by $16 \%$.

Among those who had made an online purchase of a gardening-related product in the three months before the study, they were more likely to have a slightly lower household income and more likely to be male (Table 5). They were also more likely to live in the northeast United States (compared with the west) but less likely to live in British Columbia, Canada. These findings were different from the online non-gardening purchase findings. Education had a similar impact on gardening and non-gardening online purchasing likelihood. Having education beyond a Bachelor's degree increased the likelihood of an online gardening purchase by at least $4 \%$. Unlike non-gardening online purchases, as smartphone use increased, the likelihood of 
Table 4. Comparison of 2511 North American survey participants who made an online purchase (by smartphone or other connected device) for a non-gardening product in the three months before the study with those who did not.

\begin{tabular}{|c|c|c|c|c|}
\hline \multirow[b]{2}{*}{ Variables } & \multicolumn{4}{|c|}{$\begin{array}{l}\text { Made an online purchase } \\
\text { not gardening-related }\end{array}$} \\
\hline & Coefficients $^{\mathrm{z}}$ & $\begin{array}{c}P \\
\text { value }\end{array}$ & $\begin{array}{c}\text { Marginal } \\
\text { effects }\end{array}$ & $\begin{array}{c}P \\
\text { value }\end{array}$ \\
\hline Household income (thousand dollars) & 0.0007 & 0.338 & 0.0003 & 0.338 \\
\hline Age (years) & -0.0005 & 0.794 & -0.0002 & 0.794 \\
\hline Gender (percent female) & -0.0862 & 0.103 & -0.0341 & 0.103 \\
\hline Number of persons $\geq$ adults in household & -0.0207 & 0.357 & -0.0082 & 0.357 \\
\hline Number of persons $\geq$ children in household & -0.0258 & 0.323 & -0.0102 & 0.323 \\
\hline Race: Caucasian (compared with "other ethnic" base) & 0.1204 & 0.161 & 0.0478 & 0.162 \\
\hline $\begin{array}{l}\text { Race: African/Caribbean } \\
\text { (compared with "other ethnic" base) }\end{array}$ & -0.2226 & 0.107 & -0.0886 & 0.107 \\
\hline Race: Hispanic (compared with "other ethnic" base) & -0.1077 & 0.448 & -0.0428 & 0.449 \\
\hline Live in metropolitan area (compared with rural) & 0.0137 & 0.861 & 0.0054 & 0.861 \\
\hline Live in suburban area (compared with rural) & -0.0812 & 0.234 & -0.0321 & 0.234 \\
\hline Region: northeast U.S. (compared with west U.S.) & 0.1352 & 0.140 & 0.0531 & 0.136 \\
\hline Region: midwest U.S. (compared with west U.S.) & 0.0726 & 0.423 & 0.0286 & 0.421 \\
\hline Region: south U.S. (compared with west U.S.) & 0.1350 & 0.133 & 0.0530 & 0.129 \\
\hline Region: west Canada (compared with west U.S.) & -0.2739 & 0.081 & -0.1089 & 0.079 \\
\hline Region: Ontario, Canada (compared with west U.S.) & -0.1765 & 0.078 & -0.0702 & 0.078 \\
\hline Region: Atlantic Canada (compared with west U.S.) & -0.4070 & 0.000 & -0.1612 & 0.000 \\
\hline $\begin{array}{l}\text { Region: British Columbia, Canada } \\
\text { (compared with west U.S.) }\end{array}$ & -0.1451 & 0.320 & -0.0577 & 0.321 \\
\hline Region: Quebec (compared with west U.S.) & -0.4374 & 0.219 & -0.1725 & 0.203 \\
\hline $\begin{array}{l}\text { Education: some college } \\
\text { (compared with high school or less) }\end{array}$ & 0.2734 & 0.000 & 0.1074 & 0.000 \\
\hline $\begin{array}{l}\text { Education: Bachelor's degree } \\
\text { (compared with high school or less) }\end{array}$ & 0.2381 & 0.002 & 0.0931 & 0.002 \\
\hline $\begin{array}{l}\text { Education: greater than Bachelor's degree } \\
\text { (compared with high school or less) }\end{array}$ & 0.3865 & 0.000 & 0.1473 & 0.000 \\
\hline Smartphone Internet/app use: days per week & -0.0285 & 0.002 & -0.0113 & 0.002 \\
\hline Had seen the QR code or symbol & 0.1767 & 0.002 & 0.0700 & 0.002 \\
\hline Garden expenditures during last six months & 0.0006 & 0.021 & 0.0002 & 0.021 \\
\hline Sought information but not about gardening & 0.3987 & 0.000 & 0.1580 & 0.000 \\
\hline Constant & -0.4506 & 0.014 & - & - \\
\hline Wald $\chi^{2}$ & & & 138.1 & \\
\hline$P$ value & & & 0.000 & \\
\hline log pseudolikelihood & & & 662.9 & \\
\hline
\end{tabular}

${ }^{\mathrm{z}}$ Coefficients are multiplied by 1000 .

${ }^{y}$ Consumers of Northern Canadian provinces are excluded from the analysis because there is too little variation within the dependent variable.

$\mathrm{QR}=$ quick response.

Bold text denotes significant difference at $p<0.10$.

an online gardening purchase by $0.78 \%$ for each day of increased use, but seeing the QR code did not. Increased gardening expenditures slightly increased the likelihood of online gardening purchases. Seeking information online about gardening increased the likelihood of an online gardening purchase by $19 \%$. Those who had purchased an online gardening product were similar to those who had not in age, ethnicity, likelihood of living in a metropolitan area, smartphone ownership, and having seen a QR code or symbol.

Hypothesis 2 was not supported as a result of the demographic differences between individuals who purchased non-gardening and gardening products online. However, Hypothesis 3 was supported with online gardening search behavior resulting in a $19 \%$ increase in the probability of an online gardening purchase.

\section{Conclusions}

As the adoption of smartphones escalated in the past decade across many consumer segments, marketers as never before are seeking effective strategies to understand and behaviors. The online survey was conducted in 2011, which was an essential year for the mobile communications industry with a surge of smartphone use as means of navigating through rapidly increasing cross-platform social networking and digital media consumption through these networks.

Survey data supported two of the three hypotheses tested in the study, and those two supported hypotheses were geared toward investigating differences in demographic and behavioral variables between individuals with regard to online search, smartphone ownership, and QR code familiarity. Online search and shopping behavior was examined for two product categories: gardening products and non-gardening-related products. The extent to which gardening and non-gardening-related online searches and consumption patterns are similar (or different) may have important implications on the way gardening products and related supplies can be marketed. The results showed that although females are relatively similar in their online search behavior for both gardening and non-gardening products (i.e., more likely to search than males), males are more likely to make the actual purchase (for gardening products) online. This leads to an interesting research question: whether an impulsive buying characteristic has any impact on search vs. purchase behaviors. To investigate this conjecture further, we are investigating the relationship between buying impulsiveness scale and choice decisionmaking in a parallel study.

Perhaps one of the more interesting questions that the results of this study led us to think about is the extent to which search of information leads to the actual online purchase. In the case of non-gardening products, females (compared with males) are more likely to search for information online, but the relative likelihood of making an online purchase was not found to be statistically significant. Likewise, we found that Caucasian participants were 7\% more likely to have made nongardening-related searches, but the likelihood for making an online purchase was not significant. Alternatively, participants of African/ Caribbean descent were less likely to both search and purchase online, which is relatively consistent with a presumably positive relationship between search for information and subsequent purchase. However, statistically significant positive marginal effects for search likelihood coupled with non-significant purchase likelihood does not provide sufficient information about the linkages between the two behaviors.

The results for online search and purchase behaviors with respect to gardening products, however, were different. We found that females are more likely to search for gardening products but less likely (compared with males) to make an online purchase. This may be partially explained by a relatively larger portion of female shoppers at brick and mortar garden centers (i.e., females tend to search for information using smartphones but prefer shopping at brick and mortar establishments). In contrast, males were more likely to make an 
Table 5. Comparison of 2511 North American survey participants who made an online purchase (by smartphone or other connected device) for a gardening product in the three months before the study with those who did not.

\begin{tabular}{|c|c|c|c|c|}
\hline \multirow[b]{2}{*}{ Variables } & \multicolumn{4}{|c|}{$\begin{array}{l}\text { Made an online purchase } \\
\text { gardening-related }\end{array}$} \\
\hline & Coefficients $^{\mathrm{z}}$ & $\begin{array}{c}P \\
\text { value }\end{array}$ & $\begin{array}{l}\text { Marginal } \\
\text { effects }\end{array}$ & $\begin{array}{c}P \\
\text { value }\end{array}$ \\
\hline Household income (thousand dollars) & -0.0033 & 0.000 & -0.0007 & 0.000 \\
\hline Age (years) & -0.0011 & 0.683 & -0.0002 & 0.683 \\
\hline Gender (percent female) & -0.1516 & 0.023 & -0.0329 & 0.022 \\
\hline Number of persons $\geq$ adults in household & 0.0433 & 0.115 & 0.0095 & 0.115 \\
\hline Number of persons $\geq$ children in household & 0.0404 & 0.214 & 0.0088 & 0.215 \\
\hline Race: Caucasian (compared with "other ethnic" base) & -0.1086 & 0.305 & -0.0246 & 0.322 \\
\hline $\begin{array}{l}\text { Race: African/Caribbean } \\
\text { (compared with "other ethnic" base) }\end{array}$ & -0.0394 & 0.820 & -0.0085 & 0.816 \\
\hline Race: Hispanic (compared with "other ethnic" base) & -0.1864 & 0.288 & -0.0371 & 0.239 \\
\hline Live in metropolitan area (compared with rural) & -0.1067 & 0.267 & -0.0227 & 0.253 \\
\hline Live in suburban area (compared with rural) & -0.1177 & 0.157 & -0.0258 & 0.158 \\
\hline Region: northeast U.S. (compared with west U.S.) & 0.2409 & 0.034 & 0.0573 & 0.049 \\
\hline Region: midwest U.S. (compared with west U.S.) & -0.0206 & 0.856 & -0.0045 & 0.855 \\
\hline Region: south U.S. (compared with west U.S.) & 0.1035 & 0.359 & 0.0235 & 0.375 \\
\hline Region: west Canada (compared with west U.S.) & -0.0287 & 0.889 & -0.0062 & 0.887 \\
\hline Region: Ontario, Canada (compared with west U.S.) & -0.0631 & 0.628 & -0.0134 & 0.618 \\
\hline Region: Atlantic Canada (compared with west U.S.) & -0.1262 & 0.352 & -0.0262 & 0.325 \\
\hline $\begin{array}{l}\text { Region: British Columbia, Canada } \\
\text { (compared with west U.S.) }\end{array}$ & -0.3195 & 0.078 & -0.0590 & 0.033 \\
\hline Region: Quebec (compared with west U.S.) ${ }^{\mathrm{y}}$ & 0.3769 & 0.451 & 0.0993 & 0.518 \\
\hline $\begin{array}{l}\text { Education: some college } \\
\text { (compared with high school or less) }\end{array}$ & 0.0674 & 0.453 & 0.0149 & 0.456 \\
\hline $\begin{array}{l}\text { Education: Bachelor's degree } \\
\text { (compared with high school or less) }\end{array}$ & 0.1819 & 0.060 & 0.0416 & 0.071 \\
\hline $\begin{array}{l}\text { Education: greater than Bachelor's degree } \\
\text { (compared with high school or less) }\end{array}$ & 0.2773 & 0.025 & 0.0680 & 0.0 \\
\hline Smartphone Internet/app use: days per week & 0.0356 & 0.001 & 0.0078 & 0.001 \\
\hline Had seen the QR code or symbol & 0.0179 & 0.804 & 0.0039 & 0.803 \\
\hline Garden expenditures during last six months & 0.0027 & 0.000 & 0.0006 & 0.000 \\
\hline Sought information but not about gardening & 0.8337 & 0.000 & 0.1888 & 0.000 \\
\hline Constant & -1.6305 & 0.000 & - & - \\
\hline Wald $\chi^{2}$ & & & 367.1 & \\
\hline$P$ value & & & 0.000 & \\
\hline log pseudolikelihood & & & -976.3 & \\
\hline
\end{tabular}

${ }^{\mathrm{z} C o e f f i c i e n t s ~ a r e ~ m u l t i p l i e d ~ b y ~} 1000$.

${ }^{\mathrm{y}}$ Consumers of Northern Canadian provinces are excluded from the analysis because there is too little variation within the dependent variable.

$\mathrm{QR}=$ quick response.

Bold text denotes significant difference at $p<0.10$.

online purchase and less likely to search for information about gardening products.

Geographic location of residence played a role in search and purchase likelihood. Participants in several Canadian regions had a higher non-gardening online search rate but lower non-gardening online purchase likelihood compared with the western United States. This played a smaller role in online gardening purchase likelihood but not online gardening search behavior.

The likelihood of online search and purchase behavior by residence location (i.e., metropolitan and suburban areas compared with rural) were found to be significant only for the gardening products category and only for online search likelihood. The negative relationship between residence location and likelihood for online search/purchase is somewhat correlated with the positive signs for education variables. Higher education levels were found to be positively correlated with both online search and purchase behaviors (i.e., higher education may be associated with existing/greater knowledge about certain features/characteristics of gardening products, increased the likelihood of an online purchase by $16 \%$, whereas the likelihood of purchase increased to $19 \%$ for online gardening-related searches. The implications of this finding are clear for horticultural professionals. Having relevant and compelling content on a web site that can be easily accessed by both mobile and non-mobile devices has the potential to increase online purchases substantially.

\section{Literature Cited}

American Fact Finder. 2012. 2010 American community survey 1-year estimates. 17 Sept. 2012. $<$ http://factfinder2.census.gov/faces/tableservices/ jsf/pages/productview.xhtml?pid=ACS_10_1YR_ S0101\&prodType $=$ table $>$.

Behe, B.K., B. Campbell, J. Dennis, C. Hall, R. Lopez, and C. Yue. 2010. Gardening consumer segments vary in eco-practices. HortScience 45:1475-1479.

Behe, B.K., B. Harte, and C. Yue. 2008. Online gardening search activities and purchases. J. Environ. Hort. 26:210-216.

Caron, J. 2012. For mobile commerce: The year of convergence. $19 \mathrm{Feb} .2012$. <http://www.forbes. $\mathrm{com} /$ sites/ciocentral/2012/01/16/for-mobilecommerce-the-year-of-convergence-and-context $>$.

comScore. 2012. Mobile future in focus. $19 \mathrm{Feb}$ 2012. <http://www.comscore.com/Press_Events/ Presentations_Whitepapers/2012/2012_Mobile_ Future_in_Focus>.

Davidson, R. and J.G. MacKinnon. 1993. Estimation and inference in econometrics. Oxford University Press, New York, NY.

DeNavis-Walt, C., B.D. Proctor, and J.C. Smith. 2012. Income, poverty, and health insurance coverage in the United States: 2011. Curr. Popul. Rep. [Spec Censuses] 60-243. 29 Dec. 2012. <http://www.census.gov/prod/2012pubs/ p60-243.pdf $>$.

Dennis, J.H. and B.K. Behe. 2007. Evaluating the role of ethnicity on gardening purchases and satisfaction. HortScience 42:262-266.

Dillman, D., J. Smyth, and L. Christian. 2009. Internet, mail, and mixed-mode surveys: The tailored design method. John Wiley \& Sons, Inc., NJ.

Freedman, L. 2011. The 'shopping' mindset of the mobile consumer. 19 Feb. 2012. <http:// shopcoffeetable.com/wp-content/uploads/2011/ 05/e-Tailing-Whitepaper-March-2011.pdfs.

Google/IPSOS. 2011. The mobile movement. 19 Feb. 2012. <http://www.thinkwithgoogle.com/ insights/library/studies/the-mobile-movement/>.

Hodges, A., M.A. Palma, and C.R. Hall. 2010. Trade flows and marketing practices within the U.S. nursery industry: 2008. Southern Coop. Series Bull. \#411. ISBN 1-58161-411.

InsightExpress. 2012. 1Q2012 Digital consumer portrait. 19 Feb. 2012. <http://www.insightexpress. com/pdfs/InsightExpress_1Q2012DigitalConsume Portrait_Jan2012.pdf $>$.

Mason, S., T. Starman, R.D. Lineberger, and B.K. Behe. 2008. Consumer preferences for price, color harmony and care information of container gardens. HortScience 43:380-384.

McCullough, D. 1998. Web-based market research: The dawning of a new age. Direct Marketing 61:36-38.

McKinsey \& Company. 2011. The world gone digital: Insights from McKinsey's global consumer research. 19 Feb. 2012. <http://www.mckinsey. $\mathrm{com} / \mathrm{media} /$ The_world_gone_digital.ashx $>$.

Oracle ATG Web Commerce. 2011. Mobile trends: Consumer views of mobile shopping and mobile service providers. 19 Feb. 2012.<http:// 
shopcoffeetable.com/wp-content/uploads/2011/ 05/e-Tailing-Whitepaper-March-2011.pdf $>$.

Endeca, O. 2012. E-commerce trends for 2012: Mobile and Facebook take center stage as online retailers focus on customers' digital experiences. 19 Feb. 2012. <http://www.oracle.com/ us/products/applications/ecommerce-trends-20121504949.pdf .

World, P.C. 2012. Encyclopedia. Smartphones. 19 Nov. 2012. <http://www.pcmag.com/encyclopedia term $/ 0,2542, \mathrm{t}=$ Smartphone $\& \mathrm{i}=51537,00$.asp $>$.

Pew Research Center. 2012. The rise of in-store mobile commerce. 19 Feb. 2012. <http://pewinternet.org/ Reports/2012/In-store-mobile-commerce.aspx> .
Pricegrabber.com. 2011. Smartphone shopping behavior. 19 Feb. 2012. <https://mr.pricegrabber. com/Smartphone_Shopping_Behavior_CBR. pdf>.

Statistics Canada a. 19 Feb. 2012. <http:// www12.statcan.gc.ca/census-recensement/2011/ dp-pd/hlt-fst/as-sa/Pages/highlight.cfm?TabID= $1 \&$ Lang $=\mathrm{E} \& \mathrm{PRCode}=01 \& \mathrm{Asc}=0 \&$ OrderBy $=$ $1 \& \mathrm{Sex}=2 \&$ View $=1 \&$ tableID $=22>$.

Statistics Canada b. 19 Feb. 2012. <http://www12. statcan.ca/census-recensement/2006/dp-pd/hlt/ 97-562/pages/page.cfm?Lang $=\mathrm{E} \& \mathrm{Geo}=\mathrm{PR} \&$ Code $=01 \&$ Data $=$ Count $\&$ Table $=2 \&$ StartRec $=$ $1 \&$ Sort $=3 \&$ Display $=$ All $\&$ CSDFilter $=5000>$.
Statistics Canada c. 29 Dec. 2012. <http://www. statcan.gc.ca/tables-tableaux/sum-som/101/cst01/ famil21a-eng.htm>.

TechBargains.com. 2012. 2011 holiday mobile shopping survey. 19 Feb. 2012. <http://www. businesswire.com/news/home/20111130005383/ en/Holiday-Survey-Shows-Holiday-BudgetSpent-Electronics $>$.

U.S. Department of Commerce. Economics \& Statistics Administration. 2011. Exploring the digital nation-Computer and Internet use at home. 19 Nov. 2012. <http://www.esa.doc. gov/Reports/exploring-digital-nation-computerand-internet-use-home>. 